Meta

Journal des traducteurs

Translators' Journal

\title{
Cognition and Translation Didactics
}

\section{Karin Riedemann Hall}

Volume 41, numéro 1, mars 1996

Le(s) processus de traduction / Translation Process(es)

URI : https://id.erudit.org/iderudit/002999ar

DOI : https://doi.org/10.7202/002999ar

Aller au sommaire du numéro

Éditeur(s)

Les Presses de l'Université de Montréal

ISSN

0026-0452 (imprimé)

1492-1421 (numérique)

Découvrir la revue

Citer cet article

Riedemann Hall, K. (1996). Cognition and Translation Didactics. Meta, 41(1), 114-117. https://doi.org/10.7202/002999ar

\section{Résumé de l'article}

Le but de cet article est de fournir une vue d'ensemble sur une recherche empirique menée, durant trois semestres consécutifs, sur un même groupe d'étudiants de traduction littéraire. L'auteur souhaite changer la didactique traditionnelle de la traduction en se servant de méthodes cognitives et pragmatiques pour maximiser la production et pour augmenter la capacité d'auto-correction des étudiants.
Tous droits réservés @ Les Presses de l'Université de Montréal, 1996
Ce document est protégé par la loi sur le droit d'auteur. L’utilisation des services d'Érudit (y compris la reproduction) est assujettie à sa politique d'utilisation que vous pouvez consulter en ligne.

https://apropos.erudit.org/fr/usagers/politique-dutilisation/ 


\title{
COGNITION AND TRANSLATION DIDACTICS
}

\author{
KaRIN RiEDEMANN HALl \\ Universidad Tecnologica Vicente Perez Rosales and Pontificia Universidad Católica de Chile, Santiago, Chile
}

\begin{abstract}
Résumé
Le but de cet article est de fournir une vue d'ensemble sur une recherche empirique menée, durant trois semestres consécutifs, sur un même groupe d'étudiants de traduction littéraire. L'auteur souhaite changer la didactique traditionnelle de la traduction en se servant de méthodes cognitives et pragmatiques pour maximiser la production et pour augmenter la capacité d'auto-correction des étudiants.
\end{abstract}

Abstract

The aim of this paper is to provide an overview of empirical research done with the same group of students during consecutive semesters of literary translation courses. We intend to change traditional translation didactics by using cognitive and pragmatic methods in order to optimize translation production and the student's self-correction awareness.

We want to define translation as an interlingual and intercultural communicative process at the text level. Pragmatic translation theories situate the act of translating within a communicative frame. The concept of language in use (Morris 1938) and the language as a form of social action (Halliday 1982) implying a communicative orientation with a specific intention is the core of the subject.

The linguistic action, as considered in the pragmatic approach to translation adopts a psycholinguistic or cognitive approach in present translation studies. This approach tries to investigate and to describe the intentions of the translator as a human being; it shows that the translator tries not only to communicate what a specific text says but also stresses the fact that he or she (the translator) is embedded in a specific culture at a given time and place.

With the opening up of translation studies different from linguistics, there has been a reorientation of scientific research which tends to be more objective, and more applicable. We have up-to-date tools borrowed from other fields of study, for example from psychology. These have been discovered through linguistics, essentially through Krings (1986). Nevertheless we can point out as precursors in the area of psycholinguistics important researchers as Hörmann (1981), Lörscher (1987), Königs (1987, 1991), and Neubert (1985).

Text comprehension in the source language is one of the important steps in the translation process. What we will try to develop is the idea that there are affective elements which affect the text comprehension process. Therefore it is important to define some comprehension factors. Since communication with the world is by means of our senses, we first capture various aspects which are processed, organized, and integrated afterwards; i.e. they are not part of our previous knowledge of things. Königs (1993: 233ff.) puts forth five hypotheses in order to explain translational text-comprehension: 
"1. Der übersetzungsbezogene Verstehensprozess des Ausgangtextes setzt bei Worten, nicht bei Sätzen oder ganzen Texten an...

2. Der Verstehensprozess sollte tendenziell eher bottom up erfolgen, d.h. er beginnt bei einzelnen sprachlichen Elementen und baut sich dann sukzessive unter Herausziehung nicht sprachlicher Informationen auf.

3. Interferenzen sollten stärker auf semantischer Ebene vorkommen, weniger auf syntaktischer Ebene.

4. Die Psycholinguistik ordnet in der zeitlichen Abfolge Informationen üher Text - Textwelt - und Diskursmodelle der Erkennung und Bedeutungserschließung von einzelnen Wörten nach. Trifft dies zu, müßte dies für die Erstellung einer Übersetzung Auswirkungen haben.

5. Wenn Verstehen von Texten bottom up vor sich geht, dann dürften affektive Einschätzungen des Textes dem Prozess des Verstehens nicht oder ex post facto berühren."

As we can see, the cognitive perspective proposes the study of text comprehension itself in which the description of the mental processes involved is of vital importance. Thus, the concept of "Weltanschauung" becomes the necessary supporting concept for acknowledging this point of view. The act of comprehending has a strong cultural component. Comprehending a text is mainly individual and a translator always reads a text in order to decode it and decide on translation strategies. When information reaches the brain, the brain processes it at different levels as mentioned above. Here are the important steps:

a) understanding the intention of the text;

b) activating the new acquired knowledge; and

c) activating the affective feeling toward a specific text. cesses:

Königs (1987) states that in the act of comprehending there are two types of pro-

a) The bottom up process, in which we try to comprehend the words as singular units; and

b) the top down process in which we search for connections.

For text comprehension we need both processes. The competence level of each one is what determines the interconnections established between the bottom up and the top down processes.

The empirical methods used with the students were:

a) the thinking-aloud method;

b) a variation of the former to write down a protocol about the given translation task; and

c) class discussion about the overall feeling about texts.

Before describing the way I worked with my students, I have to explain that during a translation seminar in Munich (1988) I was myself confronted with the thinking-aloud process. That experience changed my whole perspective of translation studies and didactic approaches. It was as if I had discovered a new world of possibilities, not only for me as a professional translator, but also for my students at the "Technological University" Vicente Perez Rosales and at the Catholic University in Santiago de Chile to improve and develop translation competence. After this seminar, I did graduate studies in applied linguistics specializing in pragmatic and cognitive aspects of translation and its cultural aspects.

My first attempt at varying the traditional approach in teaching translation courses was in literary translation with a group of five students: Roswitha, Malena, Francisca, Paula and Anita. The five of them had little experience in translating. Their mother tongue is Spanish but two of them can be considered bilingual (Spanish-German) and all 
of them have studied German and English as second languages. They were not selected for a specific empirical investigation; they were all from the same course, although their language performance is not the same. The importance of this is that, as a translation teacher, I am not doing research only with the intention of applying results years later to other groups, but also to improve translation competence by introducing innovative patterns at the same time the model is being applied.

The students were given the same text: pages 6 and 8 from Die Garten Uhr (1980). It is a children's book written by Christa Spangenberg and illustrated by Dietlind Blech. Photocopies were handed to the students but they also had the opportunity of seeing and looking at the original in order to appreciate its graphic presentation, type of paper, color and illustrations. If one reads the text in German, one would say that it is an easy text because of the grammatical and lexical components. One important point to keep in mind is the target audience: children from 4 to 7 years old. Before understanding the translation task itself, we spoke in general about literary translation, particularly about children's literary translation, the syntagmatic and paradigmatic use of language, its concrete and abstract uses, and also about German and Chilean children and their respective cultural backgrounds.

The five students were given the same instructions in advance:

a) As you read the text and while doing the translation verbalize everything you are thinking. You have no time restriction and you can use any dictionary you need.

b) After handing in your exercise write down how you felt while thinking aloud: did you like the text? (if not, why?). What was your reaction to a children's literary text? Did you make any associations with your own experience of the world? (In order not to interfere with the thinking-aloud process, this part was introduced to the students after they had finished step (a).)

The transcription of the tapes showed results similar to those obtained when I did the experience myself:

a) translation students read the text for the first time always searching for translation strategies;

b) in almost all cases they did not read the text completely;

c) they began doing the translation from the very beginning;

d) they never did discourse analysis at the grammatical or syntactic level;

e) they began detecting translation problems at the lexical and afterwards at the semantic and then the pragmatical level;

f) associations were always present;

g) they verbalized about the need to use a dictionary, but never used one;

h) positive psychological predisposition to the text made them enjoy translating it;

i) there is no direct ratio between translation competence and foreign language competence. (Students with excellent foreign language competence and therefore a good comprehension level did not always have a good performance in translating into Spanish. I would say that this is mainly due to interference problems caused by their bilingualism, not at semantic level but at the syntactic and pragmatic levels.)

After finishing the thinking-aloud process, students went home with the second part described above. Results here were enlightening and gave me a way of introducing the psycholinguistic aspects of translation since they were working by themselves with the text. They not only expressed their feeling towards the translation task itself, but described problems and solutions, and also how they felt during instrospection.

As we all know at universities in our countries we do not always have the time and infrastructure to confront every new group of students with this type of experience in 
order to optimize their performance. Nevertheless, I have tried through written protocols to create a different way of searching in every student's brain. In addition they are given practical exercises using approaches such as those proposed by Reiss, House, Nord and Hönig. For example, when they have to write a translation which will be evaluated they do the translation at home and must follow specific instructions. For example, the time limit set is a very important factor. In their final draft, they are required to leave all the corrections they do during translation in order to let me know what they were thinking during self-correction. (Sometimes they have to write down a protocol of what else they did while translating and about the feelings they had toward the text.)

With the above-mentioned group of students, I worked three consecutive semesters. With other groups I worked only two semesters. Nevertheless, results in acquiring translation competence while working with this method of developing self-awareness in each individual student is very rewarding, and it really helps to improve translation competence.

To summarize my experience, I can emphatically state, that translating is an extremely individual process which can only be partially controlled. There will always be paragraphs that can be easily translated, without problems. There are procedures which are not automatized in which personal experience and cultural embedding are directly related to the possibility of finding solutions. In text comprehension affective factors are indeed always present; they are at the very core of the process. Empirical studies prove translation to be a non-linear process to which Lörscher (1987) refers as a "chain of spirals" or of "loops" due to paraphrasing and solution-searching techniques.

Traditional translation didactics continues to concentrate on the surface level of the text because it puts emphasis on less effective strategies in the teaching and practice of translation methodology. Psycholinguistic studies related to translation teaching emphasize understanding messages, drawing inferences from those messages as well as from the extralinguistic knowledge, and from knowledge of the communicative situation including pragmatic elements. Inferencing and paraphrasing are therefore of vital importance. After several semesters of translation and after being exposed to the cognitive approach, the students were able to internalize the whole text as a translation unit and to account for both processes - top-down and bottom-up - and recognized that they should try to proceed top-down. The final task will always be the same: to produce a text with a specific function, for an intended audience, embedded in a different situational, pragmatic and cultural context at a given place and time.

\section{REFERENCES}

HALLIDAY, M. A. K. (Ed.) (1982): El lenguaje como semiótica social, Mexico.

HÖRMANN, H. (1981): Einführung in die Psycholinguistik, Darmstadt, Wissenschaftliche Buchgesellschaft.

KÖNIGS, F. G. (1987): "Was beim Übersetzen passiert. Theoretische Aspekte, empirische Befunde und praktische Konsequenzen", Die Neueren Sprachen, 86-2, pp. 162-185.

KÖNIGS, F. G. (1993): "Text und Übersetzer: Wer macht was mit wem? Überlegungen zur Textrezeption durch den Übersetzer", J. Holz-Mänttäri and C. Nord (Eds), Traducere Navem. Festschrift für Katharina Reiß zum 70. Geburtstag, Tampere, Tampereen Yliopisto, pp. 229-248.

KRINGS, H. (1986): Was in den Köpfen von Übersetzern vorgeht. Eine empirische Untersuchung der Struktur des Übersetzungsprozesses an fortgeschrittenen Französichlernern, Tübingen.

LÖRSCHER, W. (1987): "On Analyzing Translation Performance", W. Lörscher and R. Schulze (Eds), Perspectives on Language in Performance. Studies in Linguistics, Literary Criticism, and Language Learning and Teaching. To Honour Werner Hüllen on the Occasion of His Sixtieth Birthday, 17. October 1987, Tübingen, Narr, pp. 424-440.

MORRIS, Ch. (1938): Foundations of the Theory of Signs, Chicago.

NEUBERT, A. (1985): Text and Transiation, Leipzig, VEB Enzyklopädie.

RIEDEMANN, K. (1988): "Teoría y práctica de la traducción: una experiencia psicolingüística", Documentos lingüísticos y literarios, 14, Universidad Austral de Chile, Valdivia.

RIEDEMANN, K. (1994): Traducción, lenguaje y cognición, Pontificia Universidad Católica de Chile, Santiago. 